Keywords: Borax,

borates, MCU, SWPF

Retention: Permanent

\title{
Literature Review of Boric Acid Solubility Data
}

\author{
K. P. Crapse \\ E. A. Kyser, III
}

August 2011

Savannah River National Laboratory Savannah River Nuclear Solutions, LLC Aiken, SC 29808

Prepared for the U.S. Department of Energy under contract number DE-AC09-08SR22470.

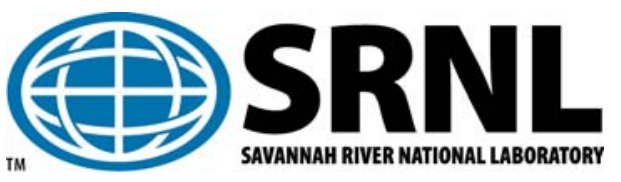


SRNL-STI-2011-00578

Revision 0

\section{DISCLAIMER}

This work was prepared under an agreement with and funded by the U.S. Government. Neither the U.S. Government or its employees, nor any of its contractors, subcontractors or their employees, makes any express or implied:

1. warranty or assumes any legal liability for the accuracy, completeness, or for the use or results of such use of any information, product, or process disclosed; or

2. representation that such use or results of such use would not infringe privately owned rights; or

3. endorsement or recommendation of any specifically identified commercial product, process, or service.

Any views and opinions of authors expressed in this work do not necessarily state or reflect those of the United States Government, or its contractors, or subcontractors.

\section{Printed in the United States of America \\ Prepared for \\ U.S. Department of Energy}




\section{REVIEWS AND APPROVALS}

AUTHORS:

K. P. Crapse, Separations and Actinide Science Programs

Date

E. A. Kyser, III, Separations and Actinide Science Programs

Date

TECHNICAL REVIEW:

T. C. Shehee, Separations and Actinide Science Programs

Date

APPROVAL:

S. D. Fink, Manager

Date

Separations and Actinide Science Programs

Date

S. L. Marra, Manager

Environmental \& Chemical Process Technology Research Programs

Terri Fellinger

Date

Waste Solidification Engineering

Beverly Oard, Manager

Date

MCU Life Extension/NGS 


\section{EXECUTIVE SUMMARY}

A new solvent system is being evaluated for use in the Modular Caustic-Side Solvent Extraction Unit (MCU) and in the Salt Waste Processing Facility (SWPF). The new system replaces the current dilute nitric acid strip solution with $0.01 \mathrm{M}$ boric acid. This literature study is performed to determine if there is a potential for boric acid to crystallize in the lines with emphasis on the transfer lines to the Defense Waste Processing Facility. This report focuses on the aqueous phase chemistry of boric acid under conditions relevant to MCU and SWPF. Operating and transfer conditions examined for the purpose of this review include temperatures between $13{ }^{\circ} \mathrm{C}$ (McLeskey, 2008) and $45^{\circ} \mathrm{C}$ (Fondeur, 2007) and concentrations from 0 to $3 \mathrm{M}$ in nitric acid as well as exposure of small amounts of entrained boric acid in the organic phase to the sodium hydroxide caustic wash stream. Experiments were also conducted to observe any chemical reactions and off-gas generation that could occur when $0.01 \mathrm{M}$ boric acid solution mixes with $3 \mathrm{M}$ nitric acid solution and vice versa.

Based on the low concentration $(0.01 \mathrm{M})$ of boric acid in the MCU/SWPF strip acid and the moderate operating temperatures $\left(13{ }^{\circ} \mathrm{C}\right.$ to $\left.45^{\circ} \mathrm{C}\right)$, it is unlikely that crystallization of boric acid will occur in the acid strip solution under process or transfer conditions. Mixing experiments of boric and nitric acid show no measurable gas generation ( $<1$ cc of gas per liter of solution) under similar process conditions. 


\section{TABLE OF CONTENTS}

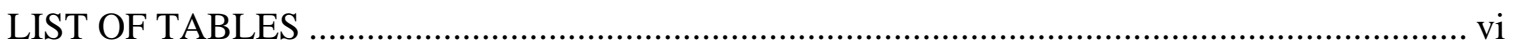

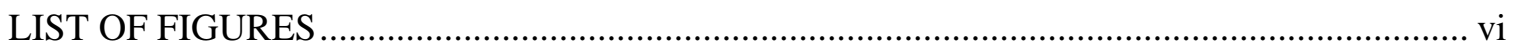

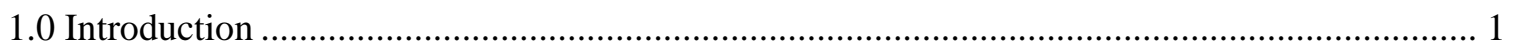

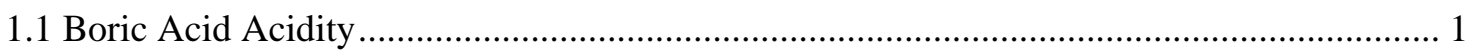

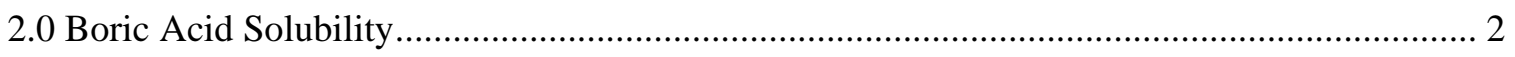

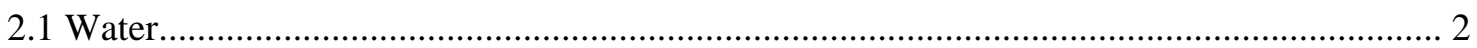

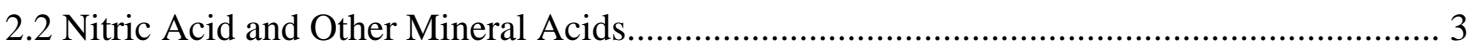

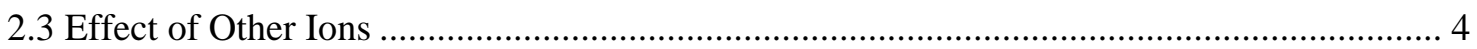

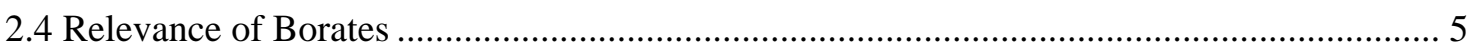

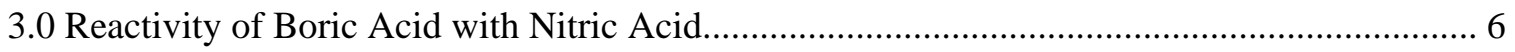

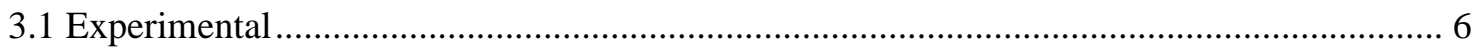

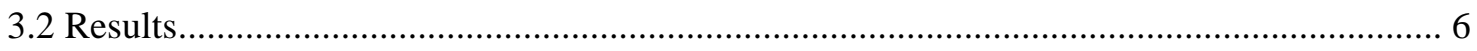

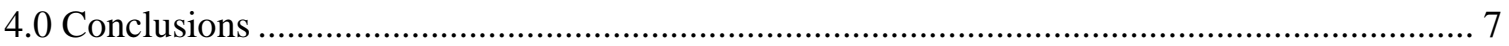

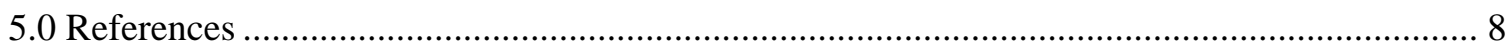

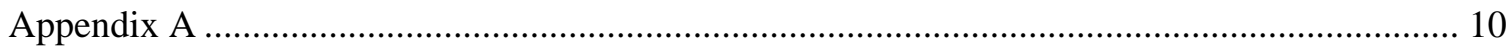

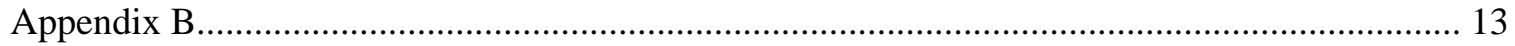

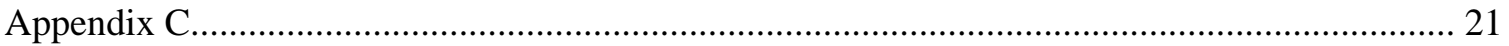




\section{LIST OF TABLES}

Table 1. Solubility of Boric Acid in Water. 11

Table 2. Solubility of Boric Acid as a Function of Nitric Acid Concentration at $25{ }^{\circ} \mathrm{C}$ (Holcomb, 1983)

Table 3. Solubility of Boric Acid in $50 \%$ Nitric Acid as a Function of Temperature (Holcomb, 1983)

Table 4. Boric Acid Solubility in $\mathrm{LiCl}, \mathrm{NaCl}, \mathrm{KCl}, \mathrm{RbCl}, \mathrm{CsCl}$, and $\mathrm{NaCl}-\mathrm{MgCl}_{2}$ Solutions at 25

${ }^{\circ} \mathrm{C}$ (Chanson, 2006). 14

Table 5. Fitting Parameters a and b for Equation 3 (Chanson, 2006). 16

Table 6. Pitzer Parameters $\lambda_{\mathrm{B}-\mathrm{i}}$ and $\zeta_{\mathrm{B}-\mathrm{a}-\mathrm{c}}$ for the Solubility of Boric Acid (Chanson, 2006)........ 18

Table 7. Partial Molal Volume of the Salts and the Best Current Estimated Salting Coefficients and Pitzer Parameter $\zeta_{\mathrm{B}-\mathrm{a}-\mathrm{c}}($ Chanson, 2006). 19

Table 8. Solubility Data in the System $\mathrm{Na}_{2} \mathrm{O}-\mathrm{B}_{2} \mathrm{O}_{3}-\mathrm{H}_{2} \mathrm{O}$ (Nies and Hulbert, 1967). 22

\section{LIST OF FIGURES}

Figure 1. Boric Acid Solubility in Water. 2

Figure 2. Boric Acid Solubility in Water versus Nitric Acid. 3

Figure 3. Boric Acid Solubility at $25{ }^{\circ} \mathrm{C}$ in $\mathrm{LiCl}, \mathrm{NaCl}, \mathrm{RbCl}$, and $\mathrm{CsCl}$ Solutions as a Function of Molality.

Figure 4. Apparatus for Measurement of Mixing Effects. 6

Figure 5. The Salting Coefficients, $\mathrm{k}_{\mathrm{s}}$, of Boric Acid in $\mathrm{HCl}, \mathrm{LiCl}, \mathrm{NaCl}, \mathrm{KCl}$, and $\mathrm{RbCl}$ as a Function of Temperature ( $\mathrm{t}$ in ${ }^{\circ} \mathrm{C}$ ) (Chanson, 2006).

Figure 6. Solubility of Sodium Borates as Compared to Boric Acid ((Blasdale and Slansky, 1939). 
SRNL-STI-2011-00578

Revision 0

\section{LIST OF ABBREVIATIONS}

CC

MCU

SWPF cubic centimeter

Modular Caustic-Side Solvent Extraction Unit

Salt Waste Processing Facility 


\subsection{Introduction}

A new solvent system is being evaluated for use in the Modular Caustic-Side Solvent Extraction Unit (MCU) and in the Salt Waste Processing Facility (SWPF). The new system replaces the current dilute nitric acid strip solution with $0.01 \mathrm{M}$ boric acid. This study is being performed to determine if there is a potential for boric acid to crystallize in the transfer lines to the Defense Waste Processing Facility (Deshpande, 2011; Newell, 2011). This report focuses on the aqueous phase chemistry of boric acid under conditions relevant to MCU and SWPF. Operating and transfer conditions are defined for the purpose of this review as temperatures between $13{ }^{\circ} \mathrm{C}$ (McLeskey, 2008) and $45^{\circ} \mathrm{C}$ (Fondeur, 2007) and concentrations from 0 to $3 \mathrm{M}$ in nitric acid. Additionally, operating conditions involving the exposure of boric acid strip solution to sodium hydroxide are considered such as exposure of the boric acid strip solution to small amounts of entrained $0.025 \mathrm{M} \mathrm{NaOH}$ scrub feed in the organic phase or small amounts of entrained boric acid in the organic phase to the $0.01 \mathrm{M}$ sodium hydroxide caustic wash stream. Also, experiments to evaluate mixing of boric acid and nitric acid were conducted to determine if any gas is generated upon mixing the boric and nitric acids.

\subsection{Boric Acid Acidity}

Boric acid is a very weak acid that acts as a Lewis acid accepting $\mathrm{OH}^{-}$rather than as a proton donor (eq 1, Cotton and Wilkinson, 1972). At concentrations less than or equal to $0.025 \mathrm{M}$, only

$$
\mathrm{B}(\mathrm{OH})_{3}+\mathrm{H}_{2} \mathrm{O}=\mathrm{B}(\mathrm{OH})_{4}{ }^{-}+\mathrm{H}^{+} \quad \mathrm{pK}=9.00 \quad \text { eq } 1
$$

monomeric species $\mathrm{B}(\mathrm{OH})_{3}$ and $\mathrm{B}(\mathrm{OH})_{4}{ }^{-}$exist.. At higher concentrations (greater than $0.025 \mathrm{M}$ ) the formation of polyborates are indicated by an increase in acidity (eq 2). These polyborates are typically ring structures or chains.

$$
3 \mathrm{~B}(\mathrm{OH})_{3}=\mathrm{B}_{3} \mathrm{O}_{3}(\mathrm{OH})_{4}{ }^{-}+\mathrm{H}^{+}+2 \mathrm{H}_{2} \mathrm{O} \quad \mathrm{pK}=6.84 \quad \text { eq } 2
$$

Hydrated borates can crystallize from aqueous solutions. Borax, $\mathrm{Na}_{2}\left[\mathrm{~B}_{4} \mathrm{O}_{5}(\mathrm{OH})_{4}\right] 8 \mathrm{H}_{2} \mathrm{O}$, the tetraborate anion, is an example of a polyborate anion. Addition of acid, such as $\mathrm{HCl}$, readily converts borax to boric acid. Rapid exchange between boric acid labeled with ${ }^{18} \mathrm{O}$ and borates indicates that equilibrium in solution is rapidly reached (Cotton and Wilkinson, 1972).

Although polyborates can be formed at higher concentrations, only mononuclear $\mathrm{B}(\mathrm{OH})_{3}$ and $\mathrm{B}(\mathrm{OH})_{4}^{-}$should be present under expected process operating conditions (i.e., boron concentrations should be $0.01 \mathrm{M}$ which is less than $0.025 \mathrm{M}$ ). The potential solubility effects of borates on MCU/SWPF process conditions are discussed in Section 2.4 below. 


\subsection{Boric Acid Solubility}

\subsection{Water}

Boric acid, $\mathrm{H}_{3} \mathrm{BO}_{3}$, is moderately soluble in water (roughly $0.4 \mathrm{M}$ at $0{ }^{\circ} \mathrm{C}, 0.9 \mathrm{M}$ at $25^{\circ} \mathrm{C}$ and $3 \mathrm{M}$ at $80^{\circ} \mathrm{C}$ ). Due to its negative heat of solution, the solubility of boric acid in water increases with temperature. Solubility data reported from several sources (Linke, 1958, Perry, 1997, Lange, 1992) is plotted in Figure 1. Appendix A includes boric acid solubility in water data. The primary reference (either directly or indirectly) for these compilations of solubility data is Blasdale and Slansky, 1939. There is some variability in these compilations even in different editions for the same source including both the data itself and the temperatures at which the data is reported. For comparison since the available data is reported in a variety of units, Figure 1 plots solubility data converted to molarity (assuming a solution density of $1 \mathrm{~g} / \mathrm{mL}$ for either water or boric acid for simplicity). Limited density data has been reported for boric acid solutions in water at $25{ }^{\circ} \mathrm{C}$ and was found to range from 0.9992 for $0.08 \mathrm{M}$ boric acid solutions to $1.0110 \mathrm{~g} / \mathrm{mL}$ for $0.6 \mathrm{M}$ boric acid (Holcomb, 1983a).

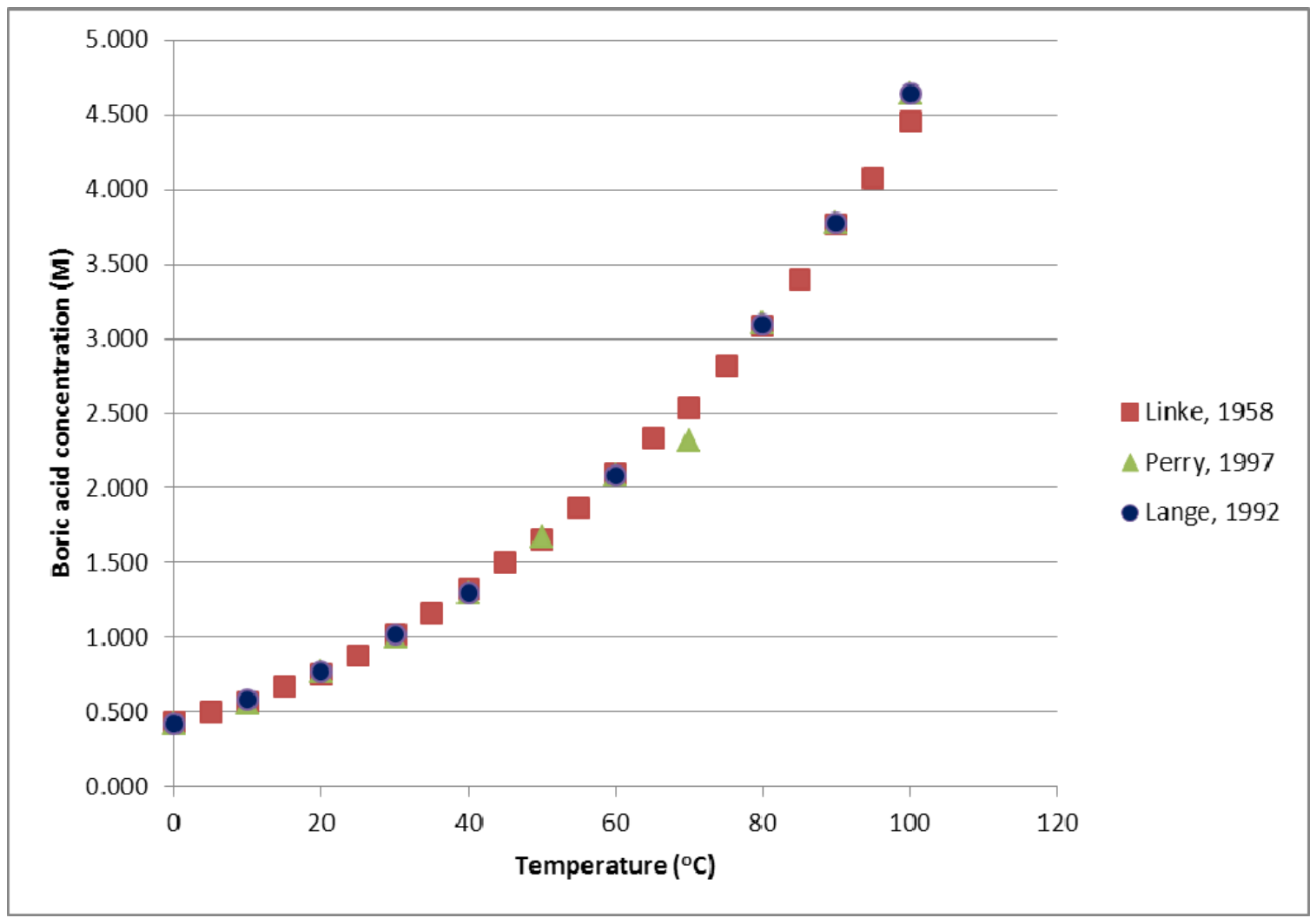

Figure 1. Boric Acid Solubility in Water. 
Thermodynamic models for aqueous solutions of boric acid (Di Giacomo, 1988) have also been reported that predict boric acid activity coefficients using experimental solubility and vapor pressure data.

Boric acid is soluble in water to greater than $0.4 \mathrm{M}$ at $0{ }^{\circ} \mathrm{C}$ (Figure 1) which is a lower temperature than process conditions expected in underground transfer lines. Therefore, no precipitation potential of $0.01 \mathrm{M}$ boric acid process solution is expected.

\subsection{Nitric Acid and Other Mineral Acids}

Nitric acid and other mineral acids (hydrochloric, sulfuric) are reported to decrease the solubility of boric acid (Linke, 1958). Figure 2 compares data for nitric acid (Holcomb, 1983) with a fit of the boric acid solubility in water. Nitric acid solubility data is included in Appendix A. At dilute concentrations of nitric acid $(<1 \mathrm{M})$, there is little effect on the solubility at $25^{\circ} \mathrm{C}$. At $25^{\circ} \mathrm{C}$ and less than $3 \mathrm{M}$ nitric acid, the solubility of boric acid is still greater than $0.5 \mathrm{M}$ which is more than an order of magnitude higher than the expected MCU/SWPF operating boric acid concentration $(0.01 \mathrm{M})$. Although literature data below $25{ }^{\circ} \mathrm{C}$ was not found, data from $25{ }^{\circ} \mathrm{C}$ to $75{ }^{\circ} \mathrm{C}$ indicate that the effect of nitric acid on the solubility is greater with increasing temperature. Making the assumption that this observed trend is valid for temperatures between $10{ }^{\circ} \mathrm{C}$ and $25^{\circ} \mathrm{C}$, the solubility of boric acid in $3 \mathrm{M}$ nitric at $13^{\circ} \mathrm{C}$ can be estimated to be greater than $0.235 \mathrm{M}^{1}$. Based

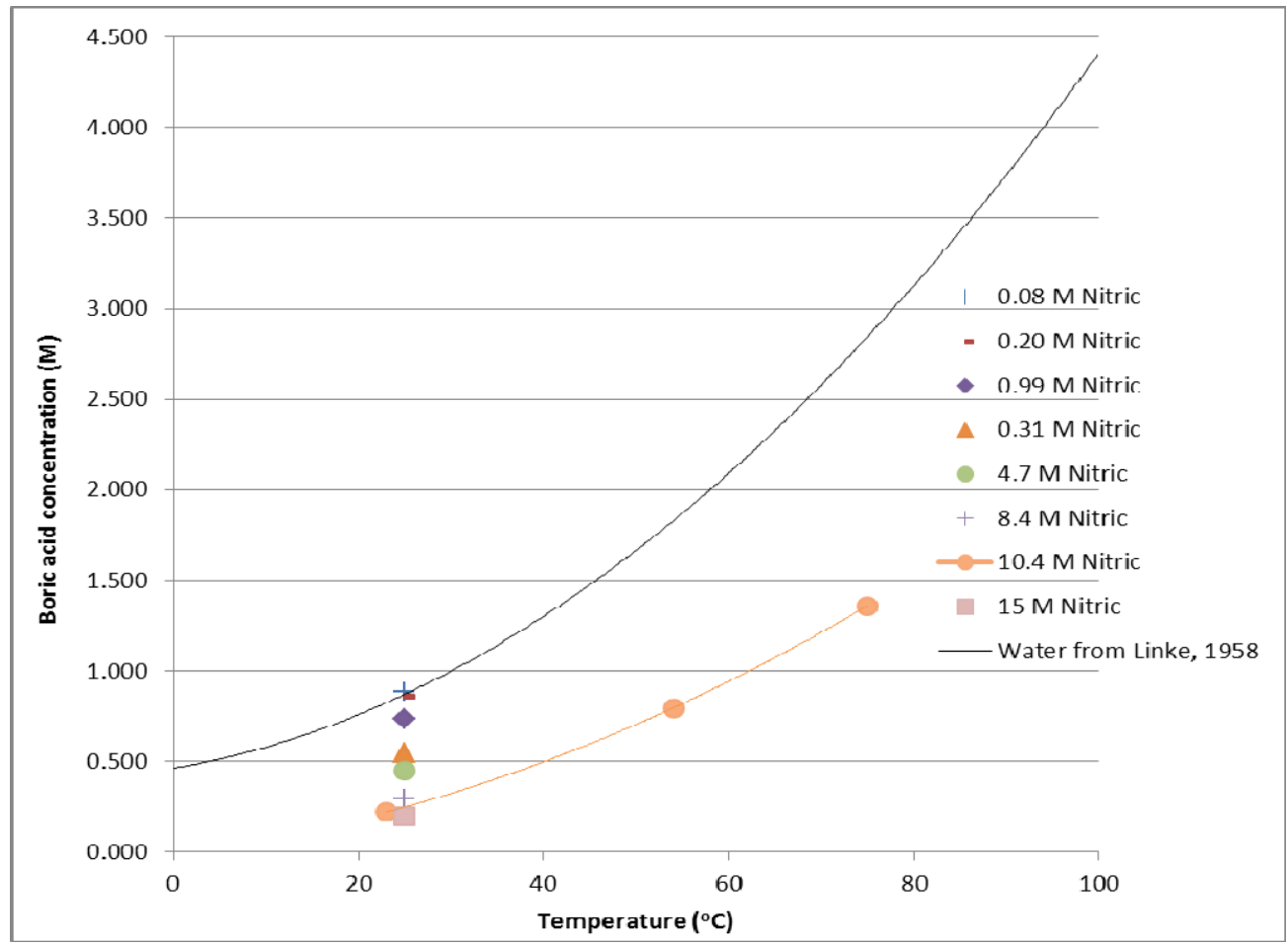

Figure 2. Boric Acid Solubility in Water versus Nitric Acid.

\footnotetext{
${ }^{1}$ At $25{ }^{\circ} \mathrm{C}$ boric acid solubility decreases from $0.878 \mathrm{M}$ in water to $0.544 \mathrm{M}$ in $3.1 \mathrm{M}$ nitric acid, Using available data for the solubility of boric acid in water at $10^{\circ} \mathrm{C}(0.569 \mathrm{M}$; a conservative assumption because the solubility of boric acid in water is greater at $13^{\circ} \mathrm{C}$ ) and assuming the same magnitude of decrease in solubility reported at $25{ }^{\circ} \mathrm{C}$ (a conservative assumption because the magnitude of the decrease in solubility at $13^{\circ} \mathrm{C}$ should be smaller), the solubility of boric acid is estimated to decrease to no lower than $0.235 \mathrm{M}$ in $3.1 \mathrm{M}$ nitric acid at $13{ }^{\circ} \mathrm{C}$.
} 
on this estimate, no precipitation of $0.01 \mathrm{M}$ boric acid in nitric acid would be expected under $\mathrm{MCU} / \mathrm{SWPF}$ processing conditions (0 to $3 \mathrm{M}$ nitric acid, and $13{ }^{\circ} \mathrm{C}$ to $45^{\circ} \mathrm{C}$ )

\subsection{Effect of Other Ions}

The solubility of boric acid in $\mathrm{LiCl}, \mathrm{NaCl}, \mathrm{KCl}, \mathrm{RbCl}$, and $\mathrm{CsCl}$ salt solutions has been determined as a function of ionic strength $(0-6 \mathrm{~mol} / \mathrm{kg})$ at $25{ }^{\circ} \mathrm{C}$ (Figure 3) (Chanson, 2006).

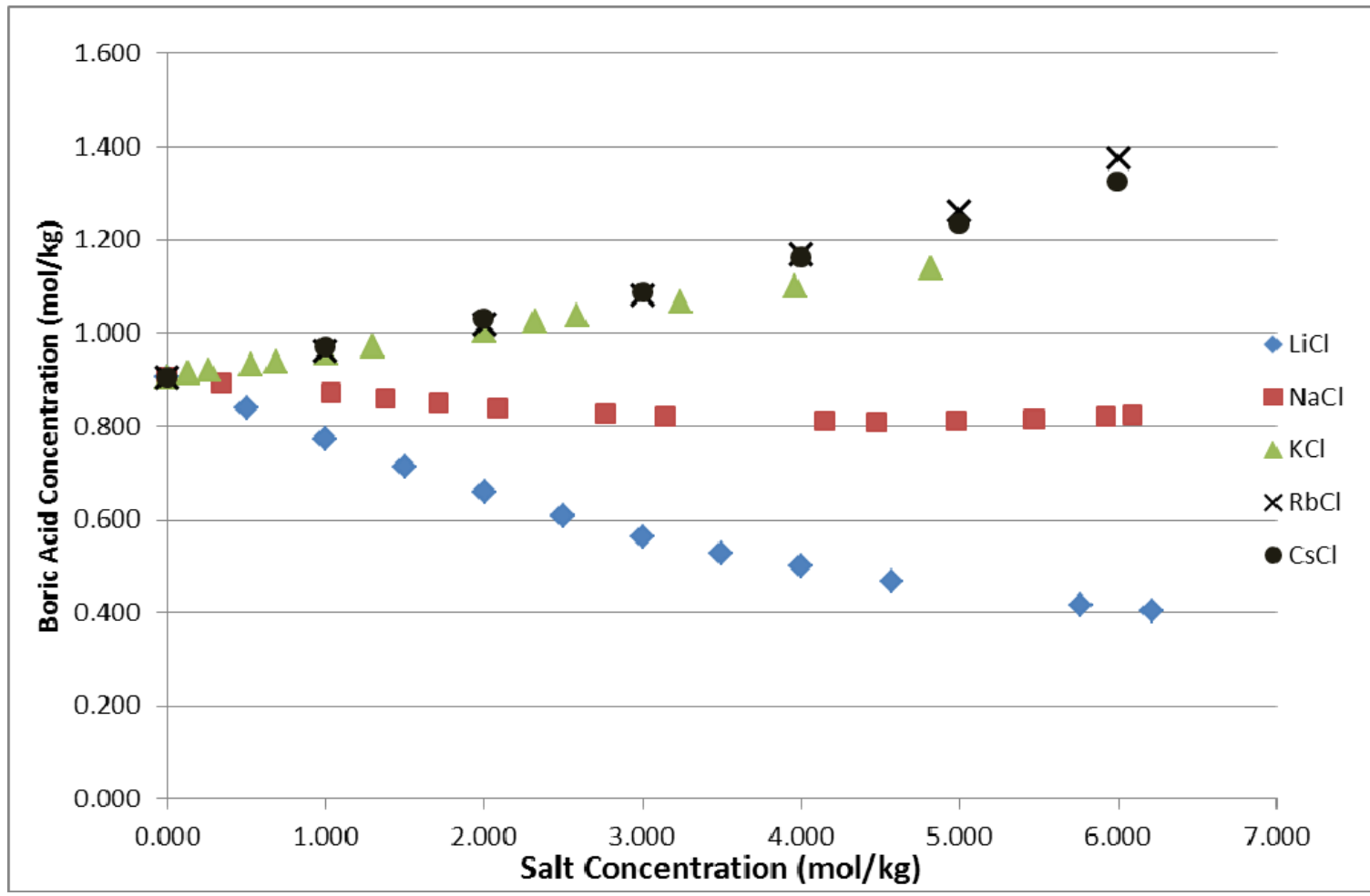

Figure 3. Boric Acid Solubility at $25^{\circ} \mathrm{C}$ in $\mathrm{LiCl}, \mathrm{NaCl}, \mathrm{RbCl}$, and $\mathrm{CsCl}$ Solutions as a Function of Molality.

These results along with literature data in terms of molal solubilities were fit to the second degree equation (eq 3)

$$
\ln \left\{[\mathrm{B}]^{0} /[\mathrm{B}]\right\}=\ln \gamma_{\mathrm{B}}=\mathrm{a} m+\mathrm{bm}^{2} \quad \text { eq } 3
$$

where $[B]^{0}$ is the concentration of boric acid in water and $[B]$ in solution, $\gamma_{B}$ is the activity coefficient, and $m$ is the salt molality. This equation is in the form of the Pitzer equation. The coefficients are related to Pitzer parameters by: $a=k_{s}=2 v_{c} \lambda_{B c}+2 v_{\mathrm{a}} \lambda_{\mathrm{Ba}}$ where $k_{\mathrm{s}}$ is the salting coefficient and $v_{\mathrm{i}}$ is the number of ions (i), and $\lambda_{\mathrm{Ba}}$ and $\lambda_{\mathrm{Bc}}$ are parameters related to the interaction of boric acid with cation (c) and anion (a), and $b=v_{\mathrm{c}} \nu_{\mathrm{a}} \zeta_{\mathrm{B}-\mathrm{a}-\mathrm{c}}$ where $\zeta_{\mathrm{B}-\mathrm{a}-\mathrm{c}}$ is related to the interaction of boric acid with both cation and anion. For 1-1 electrolytes $\zeta_{\mathrm{B}-\mathrm{a}-\mathrm{c}}$ is equal to $\mathrm{b}$. For 1-2 electrolytes $\zeta_{\mathrm{B}-\mathrm{a}-\mathrm{c}} \mathrm{is} \mathrm{b} / 2$. Appendix $\mathrm{B}$ gives detailed tables of experimental data for boric acid solubility in $\mathrm{LiCl}, \mathrm{NaCl}, \mathrm{KCl}, \mathrm{RbCl}, \mathrm{CsCl}$, and $\mathrm{NaCl}-\mathrm{MgCl}_{2}$ solutions at $25{ }^{\circ} \mathrm{C}$, fitting parameters a and $b$ (eq 3 ), $\mathrm{k}_{\mathrm{s}}$ as a function of temperature and associated adjustable parameters, and Pitzer Parameters $\lambda_{\mathrm{B}-\mathrm{i}}$ and $\zeta_{\mathrm{B}-\mathrm{a}-\mathrm{c} \text {. }}$ Although the Chanson modeling was directed at chloride systems, parameters are also provided for the effects of common nitrate salts. (The original papers should be consulted for additional detail prior to use of this model.) 
The solubility of boric acid in lithium, sodium, and potassium chloride solutions is not a strong function of temperature. Chanson (2006) recommends that salting coefficients and other parameters derived in their study can be used over the temperature range $5-35{ }^{\circ} \mathrm{C}$ because temperature appears to have little effect on $\mathrm{LiCl}, \mathrm{NaCl}$, and $\mathrm{KCl}$ solutions. Figure 5 in Appendix B shows literature data from Linke (1958) used to plot salting coefficients as a function of temperature (Chanson, 2006). Boric acid is soluble in the order: cesium $>$ rubidium $>$ potassium $>$ sodium $>$ lithium $>$ hydrogen and barium $>$ strontium $>$ calcium $>$ magnesium in common anion salt solutions (Chanson, 2006). Boric acid is soluble in the order: sulfate $>$ nitrate $>$ and fluoride $>$ chloride $>$ bromide $>$ iodide in common cation solutions (Chanson, 2006).

Thermodynamic modeling has been reported for sodium and potassium chloride solutions with boric acid in the temperature range $30-100{ }^{\circ} \mathrm{C}$ (Di Giacomo, 1993) as well as sodium and potassium sulfate (Di Giacomo, 1992). Sodium chloride appears to have little effect on the solubility of boric acid in the $30-100{ }^{\circ} \mathrm{C}$ range while potassium chloride and sodium and potassium sulfate increase solubility of boric acid and the effect increases with increasing temperature in the same range $\left(30-100^{\circ} \mathrm{C}\right)$.

\subsection{Relevance of Borates}

The formation of borates may occur on exposure of the boric acid strip solution to dilute basic solutions such as exposure of small amounts of entrained boric acid solution in the organic phase to $0.01 \mathrm{M}$ sodium hydroxide caustic wash or exposure of the boric acid strip solution to small amounts of entrained $0.025 \mathrm{M} \mathrm{NaOH}$ scrub in the organic phase. Borates, such as borax, are typically more soluble in water than boric acid (Holcomb, 1983). The system $\mathrm{Na}_{2} \mathrm{O} / \mathrm{B}_{2} \mathrm{O}_{3} / \mathrm{H}_{2} \mathrm{O}$ has been well studied (Blasdale and Slansky, 1939; Nies and Hulbert, 1967, Rothbaum et al. 1956). Appendix C includes solubility data for sodium borates (Blasdale and Slansky, 1939; Nies and Hulbert, 1967). The presence of borax has been reported to increase the solubility of more concentrated boric acid solutions presumably by the formation of polyborates (Tuunanen, 1994) even under conditions known to favor boric acid crystallization, such as high temperature sufficient to vaporize boric acid $\left(100^{\circ} \mathrm{C}\right)$, heating/cooling cycles, and evaporative loss of aqueous phase.

The presence of borates would be expected to increase the overall solubility of boron-containing species in the acid strip solution. At these dilute boric acid concentrations this increased solubility effect would only be appreciable if the MCU/SWPF process strip acid solution was concentrated to greater than or equal to $0.025 \mathrm{M}$ in boron. At the planned low initial boric acid concentrations ( $0.01 \mathrm{M}$ in the acid strip solution), only monomeric species are expected and little effect would be observed on the overall solubility of all boron containing species in an acid strip solution that has been partially neutralized by mixing with caustic solution. 


\subsection{Reactivity of Boric Acid with Nitric Acid}

Transfer lines containing $0.01 \mathrm{M}$ boric acid solution may alternatively contain $3 \mathrm{M}$ nitric acid solution. Without flushing, boric acid solution may mix in the transfer line with nitric acid and vice versa. Several experiments were performed to observe any chemical reactions and off-gas generation that could occur when these solutions are mixed.

\subsection{Experimental}

The experimental setup consisted of a $100 \mathrm{~mL}$ 3-port boiling flask fitted with a small condenser (shown in Figure 4). A $12 \mathrm{~mL}$ graduated addition funnel with gas by-pass allowed addition of boric acid to nitric acid without venting the system. Stirring was provided by a Teflon ${ }^{\circledR}$ stirring bar and hotplate with measurement of both the pressure and the solution temperature. Nitric acid was also added to boric acid. A digital manometer (with 0.01 psig resolution) was used to measure the pressure in the system. A K-type Teflon ${ }^{\circledR}$ coated thermocouple and hotplate display was used to monitor the solution temperature (with $0.1{ }^{\circ} \mathrm{C}$ resolution).

\subsection{Results}

The addition of $12 \mathrm{~mL}$ of $0.01 \mathrm{M}$ boric acid to $50 \mathrm{~mL}$ of $3.16 \mathrm{M}$ nitric acid did not result in any detectable pressure or temperature rise. Some light refraction was noted as the solutions mixed

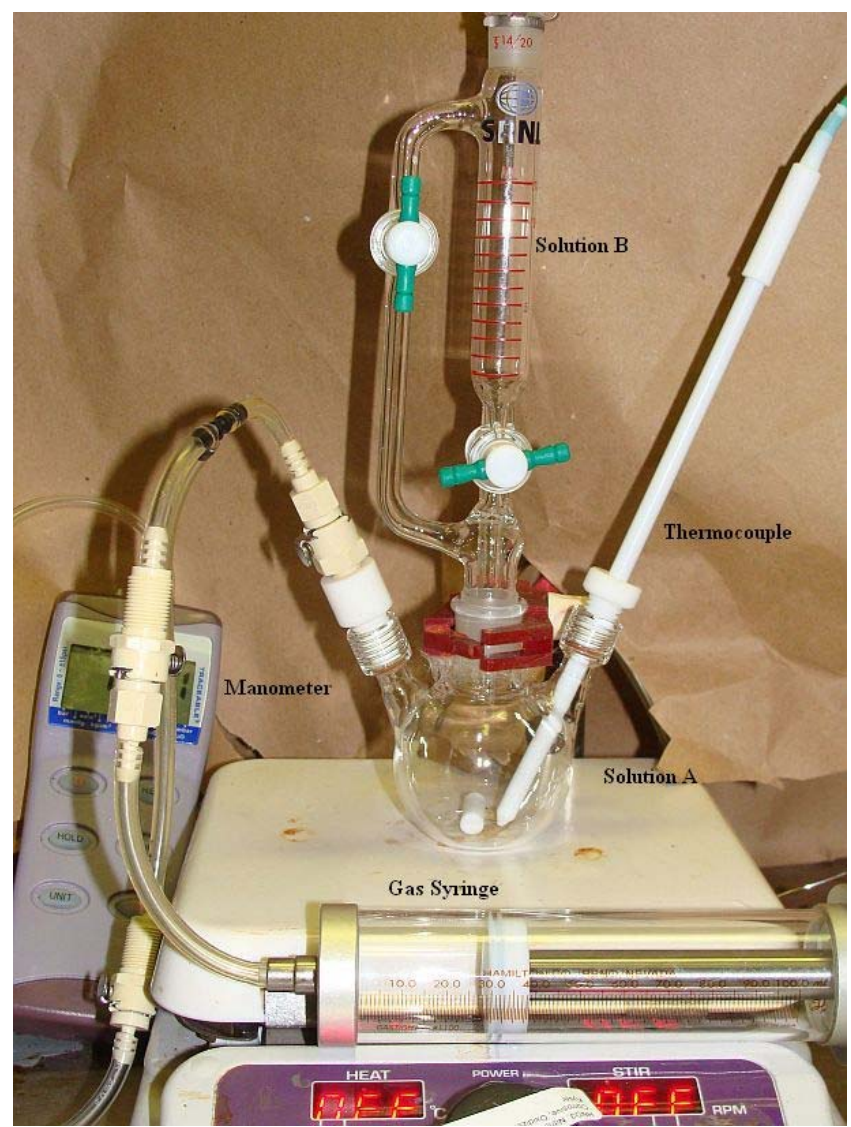

Figure 4. Apparatus for Measurement of Mixing Effects. but this quickly dissipated. There was no visible evidence of any $\mathrm{NO}_{\mathrm{x}}$ evolution. The addition of $12 \mathrm{~mL}$ of nitric acid to $50 \mathrm{~mL}$ of boric acid (same concentrations as before) gave identical result. For a test of the sensitivity, $1 \mathrm{cc}$ of air at ambient temperature and pressure was injected into the system via a gas syringe connected to the manometer line which resulted in a pressure increase of 0.14 psig. Consequently, for this experimental setup, a detectable pressure rise of 0.01 psig (digital manometer has 0.01 psig resolution) corresponds to 0.07 cC of gas generated. Based on this result, the sensitivity of this test for gas generation is estimated to be $<0.07 \mathrm{cc}$ (@18 ${ }^{\circ} \mathrm{C}$ ) or $<0.1 \mathrm{vol} \%$, for the volumes of solution that were mixed.

The mixing of solutions of $3.16 \mathrm{M}$ nitric acid and $0.01 \mathrm{M}$ boric acid did not show any evidence of significant gas generation $(<1$ cc of gas per liter of solution). 


\subsection{Conclusions}

Based on the expected low concentration $(0.01 \mathrm{M})$ of boric acid in in the MCU/SWPF process strip acid and the moderate operating temperatures $\left(13{ }^{\circ} \mathrm{C}-45^{\circ} \mathrm{C}\right)$, it is unlikely that crystallization of boric acid will occur in the acid strip solution under process conditions. If the boric acid in the strip acid is exposed to neutralizing conditions, it is unlikely that these conditions will cause the boric acid to crystallize. Rather, the formation of borates would be expected to increase the overall solubility of boron containing species in the solution. Contact of the boric acid strip solution with nitric acid solutions would be expected to reduce the solubility of boric acid. At concentrations of nitric acid less than $3 \mathrm{M}$ after mixing, the solubility of boric acid remains greater than an order of magnitude higher than the expected boric acid concentration in the acid strip solution at $25^{\circ} \mathrm{C}$. The greatest uncertainty for results of mixing nitric acid solutions and boric acid would be in the temperature range less than $25^{\circ} \mathrm{C}$ where literature data was not available. Based on estimates from available data, the solubility of boric acid between $13^{\circ} \mathrm{C}$ and $25^{\circ} \mathrm{C}$ is estimated as more than an order of magnitude higher than $0.01 \mathrm{M}$. Furthermore, conditions known to favor the formation of solids from aqueous solutions of boric acid such as elevated temperatures $\left(100^{\circ} \mathrm{C}\right)$, evaporative concentration due to breach of containment in the process lines, and heating cooling cycles are unlikely to be encountered under normal MCU/SWPF process conditions. Additionally, the mixing of $3.16 \mathrm{M}$ nitric acid and $0.01 \mathrm{M}$ boric acid do not show any evidence of significant gas generation ( $<1 \mathrm{cc}$ of gas per liter of solution). 
SRNL-STI-2011-00578

Revision 0

\subsection{References}

(Blasdale and Slansky, 1939) Blasdale, W. C. Slansky, C. M., "Solubility Curves of Boric Acid and the Borates of Sodium” J. Am. Chem. Soc. 1939, 61, 917-920.

(Chanson, 2006) Chanson, M., Millero, F. J., "The Solubility of Boric Acid in Electrolyte Solutions,”. J. Solution Chem., 2006, 35, 689-703.

(Cotton and Wilkinson, 1972) Advanced Inorganic Chemistry, A Comprehensive Text, $3^{\text {rd }}$ Edition, F. A. Cotton and G. Wilkinson, editors, John Wiley and Sons, Inc., New York, 1972

(Di Giacomo, 1988) “Thermodynamics of Aqueous Solutions of Boric Acid,” J. Solution Chem., 1988, 17, 429-434.

(Deshpande, 2011) Deshpande, M., "Technical Task Request: NGS/mMST Studies at ARP/ MCU,” SRR-WPT-2010-00004, Revision 3, May 26, 2011

(Di Giacomo, 1992) Di Giacomo, G., Brandani, P., Brandani, V. and Del Re, G.,. "Solubility of Boric Acid in Aqueous Solutions of Sulfate Salts,” Desalination 1992, 89: 185-202.

(Di Giacomo, 1993) "Solubility of Boric Acid in Aqueous Solutions of Chloride Salts," Desalination 1993, 91: 21-31.

(Fondeur, 2007) Fondeur, F. F., Poirier, M. R., Fink, S. D., "Estimation of the Temperature Rise of a MCU Acid Stream Pipe in Near Proximity to a Sludge Stream Pipe,” WSRC-STI-200700276, Westinghouse Savannah River Company, Aiken, SC, July 12, 2007.

(Holcomb, 1983) Holcomb, H. P., "Boron Solubility and Solution Studies for SEFOR Fuel Campaign,” 221H-LIB-F-62-018, DPSPU-83-272-75 May 18, 1983.

(Holcomb, 1983a) Holcomb, H. P., "Densities of Solutions of Boric Acid and Water," 221HLIB-F-62-018, August 8, 1983.

(Lange, 1992) Lange's Handbook of Chemistry, $14^{\text {th }}$ Edition, J. A. Dean, editor, McGraw-Hill, Inc., New York, 1992.

(Linke, 1958) Solubilities: Inorganic and Metal-Organic Compounds. W. F. Linke, editor, American Chemical Society, Washington, DC, 1958.

(McLeskey, 2008) McLeskey, S. P., "Salt-out evaluation for Tank 41 to Tank 49 Transfer," XCLC-H-00720, September 30, 2008.

(Newell, 2011) Newell, J. D., Peeler, D. K., “Task Technical and Quality Assurance Plan for Evaluation of DWPF Impacts of Boric Acid Use in Cesium Strip for SWPF and MCU,” SRNLRP-2010-01732, Revision 1, April 4, 2011.

(Nies and Hulbert, 1967) Nies, N. P., Hulbert, R. W., "Solubility Isotherms in the System Sodium oxide-Boric Oxide-Water, Revised Solubility-Temperature Curves of Boric Acid, Borax, Sodium Pentaborate, and Sodium Metaborate,” J. Chem. Eng. Data. 1967, 12, 303-313. 
(Perry, 1997) Perry's Chemical Engineers' Handbook ( $7^{\text {th }}$ Edition), R. H. Perry and D. W. Green editors, McGraw-Hill, New York, 1997.

(Rothbaum et al. 1956) Rothbaum, H. P., Todd, H. J., "Solubility of Some Mixtures of Alkali Borates,” J. Chem. Eng. Data Series. 1956, 1, 95-99.

(Tuunanen, 1994) Tuunanen, J. Tuomisto, J. Raussi, P., "Experimental and analytical studies of boric acid concentrations in a VVER-440 reactor during the long-term cooling period of loss-ofcoolant accidents” Nuclear Engineering and Design, 1992, 148, 217-231. 
SRNL-STI-2011-00578

Revision 0

Appendix A 
Table 1. Solubility of Boric Acid in Water.

\begin{tabular}{|c|c|c|c|}
\hline Temperature $\left({ }^{\circ} \mathrm{C}\right)$ & $\begin{array}{c}\mathrm{g} \mathrm{H}_{3} \mathrm{BO}_{3} / \\
100 \mathrm{~g} \text { sat sol w/ } \mathrm{H}_{2} \mathrm{O} \\
\text { (Linke, 1958) }\end{array}$ & $\begin{array}{c}\mathrm{g} \mathrm{H}_{3} \mathrm{BO}_{3} / \\
100 \mathrm{~g} \mathrm{H}_{2} \mathrm{O} \\
\text { (Perry, 1997) }\end{array}$ & $\begin{array}{c}\mathrm{g} \mathrm{H}_{3} \mathrm{BO}_{3} / \\
100 \mathrm{~g} \mathrm{H}_{2} \mathrm{O} \\
\text { (Lange, 1992) } \\
\end{array}$ \\
\hline 0 & 2.70 & 2.66 & 2.67 \\
\hline 5 & 3.14 & - & - \\
\hline 10 & 3.52 & 3.57 & 3.73 \\
\hline 15 & 4.17 & - & - \\
\hline 20 & 4.65 & 5.04 & 5.04 \\
\hline 25 & 5.43 & - & - \\
\hline 30 & 6.34 & 6.60 & 6.72 \\
\hline 35 & 7.19 & - & - \\
\hline 40 & 8.17 & 8.72 & 8.72 \\
\hline 45 & 9.32 & - & - \\
\hline 50 & 10.23 & 11.54 & - \\
\hline 55 & 11.54 & - & - \\
\hline 60 & 12.96 & 14.81 & 14.81 \\
\hline 65 & 14.42 & - & - \\
\hline 70 & 15.75 & 16.73 & - \\
\hline 75 & 17.40 & - & - \\
\hline 80 & 19.06 & 23.75 & 23.62 \\
\hline 85 & 21.01 & - & - \\
\hline 90 & 23.27 & 30.38 & 30.38 \\
\hline 95 & 25.22 & - & - \\
\hline 100 & 27.53 & 40.25 & 40.25 \\
\hline
\end{tabular}

- Indicates no data available at this temperature. 
Table 2. Solubility of Boric Acid as a Function of Nitric Acid Concentration at $25^{\circ} \mathrm{C}$ (Holcomb, 1983)

\begin{tabular}{|c|c|}
\hline & $\begin{array}{c}\text { moles } \\
\mathrm{H}_{3} \mathrm{BO}_{3} / \\
\text { Liter } \\
\text { saturated } \\
\text { solution } \\
\text { (moles/Liter) }\end{array}$ \\
\hline 0.0779 & 0.8820 \\
\hline 0.1951 & 0.8610 \\
\hline 0.5337 & 0.8028 \\
\hline 0.9890 & 0.7361 \\
\hline 1.580 & 0.6685 \\
\hline 2.372 & 0.5493 \\
\hline 3.118 & 0.5444 \\
\hline 3.806 & 0.4977 \\
\hline 4.698 & 0.4471 \\
\hline 8.410 & 0.2963 \\
\hline
\end{tabular}

Table 3. Solubility of Boric Acid in 50 \% Nitric Acid as a Function of Temperature (Holcomb, 1983)

\begin{tabular}{|c|c|}
\hline & $\begin{array}{c}\text { moles } \\
\mathrm{H}_{3} \mathrm{BO}_{3} / \\
\text { Liter } \\
\text { saturated } \\
\text { solution }\end{array}$ \\
\hline Temperature ${ }^{\circ} \mathrm{C}$ & 0.22 \\
\hline 23 & 0.80 \\
\hline 54 & 1.36 \\
\hline 75 &
\end{tabular}


SRNL-STI-2011-00578

Revision 0

\section{Appendix B}


Table 4. Boric Acid Solubility in LiCl, $\mathrm{NaCl}, \mathrm{KCl}, \mathrm{RbCl}, \mathrm{CsCl}$, and $\mathrm{NaCl}-\mathrm{MgCl}_{2}$ Solutions at $25^{\circ} \mathrm{C}$ (Chanson, 2006).

\begin{tabular}{|c|c|c|}
\hline$[\mathrm{B}]^{a}$ & $m^{a}$ & $\ln \left(\gamma_{B}\right)$ \\
\hline \multicolumn{3}{|l|}{$\mathrm{LiCl}$} \\
\hline 0.905 & 0.000 & 0.000 \\
\hline 0.840 & 0.501 & 0.079 \\
\hline 0.774 & 1.000 & 0.161 \\
\hline 0.712 & 1.501 & 0.245 \\
\hline 0.658 & 2.001 & 0.323 \\
\hline 0.608 & 2.500 & 0.402 \\
\hline 0.564 & 3.001 & 0.477 \\
\hline 0.528 & 3.500 & 0.542 \\
\hline 0.500 & 4.002 & 0.599 \\
\hline 0.467 & 4.572 & 0.666 \\
\hline 0.415 & 5.765 & 0.785 \\
\hline 0.405 & 6.220 & 0.808 \\
\hline \multicolumn{3}{|l|}{$\mathrm{NaCl}$} \\
\hline 0.905 & 0.000 & 0.000 \\
\hline 0.894 & 0.343 & 0.017 \\
\hline 0.871 & 1.031 & 0.044 \\
\hline 0.861 & 1.376 & 0.055 \\
\hline 0.850 & 1.717 & 0.068 \\
\hline 0.839 & 2.082 & 0.081 \\
\hline 0.826 & 2.764 & 0.096 \\
\hline 0.820 & 3.140 & 0.104 \\
\hline 0.811 & 4.146 & 0.114 \\
\hline 0.810 & 4.480 & 0.116 \\
\hline 0.811 & 4.982 & 0.115 \\
\hline 0.816 & 5.467 & 0.109 \\
\hline 0.815 & 5.472 & 0.110 \\
\hline 0.822 & 5.927 & 0.101 \\
\hline 0.825 & 6.092 & 0.097 \\
\hline \multicolumn{3}{|c|}{$\mathrm{NaCl}-\mathrm{MgCl}_{2}^{b}$} \\
\hline $0.864^{c}$ & 0.482 & 0.046 \\
\hline $0.866^{d}$ & 0.482 & 0.045 \\
\hline \multicolumn{3}{|l|}{$\mathrm{KCl}$} \\
\hline 0.905 & 0.000 & 0.000 \\
\hline 0.915 & 0.134 & -0.006 \\
\hline 0.921 & 0.267 & -0.013 \\
\hline 0.932 & 0.534 & -0.025 \\
\hline 0.939 & 0.693 & -0.032 \\
\hline 0.955 & 1.007 & -0.050 \\
\hline 0.970 & 1.303 & -0.065 \\
\hline 1.005 & 2.001 & -0.100 \\
\hline 1.024 & 2.321 & -0.119 \\
\hline 1.037 & 2.590 & -0.131 \\
\hline 1.066 & 3.241 & -0.160 \\
\hline 1.101 & 3.963 & -0.191 \\
\hline 1.139 & 4.822 & -0.226 \\
\hline
\end{tabular}


Table 4. (Continued).

\begin{tabular}{ccr}
\hline$[\mathrm{B}]^{\alpha}$ & $m^{a}$ & $\ln \left(\gamma_{\mathrm{B}}\right)$ \\
\hline $\mathrm{RbCl}$ & & \\
0.905 & 0.000 & 0.000 \\
0.963 & 1.001 & -0.058 \\
1.019 & 2.001 & -0.114 \\
1.082 & 2.999 & -0.174 \\
1.169 & 3.999 & -0.252 \\
1.261 & 4.997 & -0.327 \\
1.376 & 6.001 & -0.414 \\
$\mathrm{CsCl}$ & & \\
0.905 & 0.000 & 0.000 \\
0.971 & 0.997 & -0.066 \\
1.031 & 2.000 & -0.125 \\
1.087 & 3.002 & -0.179 \\
1.164 & 3.996 & -0.247 \\
1.234 & 4.995 & -0.306 \\
1.326 & 5.996 & -0.377 \\
\hline
\end{tabular}

${ }^{0}$ Units in $\mathrm{mol} \cdot \mathrm{kg}^{-1}$.

${ }^{b} 0.427 \mathrm{~mol} \cdot \mathrm{kg}^{-1} \mathrm{NaCl}$ and $0.055 \mathrm{~mol} \cdot \mathrm{kg}^{-1} \mathrm{MgCl}_{2}$.

'Measured.

${ }^{d}$ Calculated from Eq. (27).

Eq 27 available in the original paper by Chanson (2006). 
SRNL-STI-2011-00578

Revision 0

Table 5. Fitting Parameters a and b for Equation 3 (Chanson, 2006).

\begin{tabular}{|c|c|c|c|c|c|}
\hline Salt & Maximum $m$ & $a$ & $b$ & SD & Reference \\
\hline \multirow[t]{2}{*}{$\mathrm{HCl}$} & $1.546^{a}$ & $0.240^{a}$ & $-0.032^{a}$ & 0.003 & (3) \\
\hline & 16.031 & 0.193 & -0.009 & 0.045 & (3) \\
\hline \multirow[t]{2}{*}{$\mathrm{LiCl}$} & 6.22 & 0.178 & -0.008 & 0.009 & This study \\
\hline & 4.124 & $0.167^{b}$ & 0.000 & 0.005 & (3) \\
\hline \multirow[t]{2}{*}{$\mathrm{NaCl}$} & 6.092 & 0.047 & -0.005 & 0.002 & This study \\
\hline & 3.493 & $0.062^{c}$ & -0.010 & 0.000 & (3) \\
\hline \multirow[t]{2}{*}{$\mathrm{KCl}$} & 4.822 & -0.050 & 0.000 & 0.002 & This study \\
\hline & 3.133 & $-0.051^{d}$ & 0.001 & 0.001 & (3) \\
\hline \multirow[t]{3}{*}{$\mathrm{RbCl}$} & 6.001 & -0.053 & -0.003 & 0.003 & This study \\
\hline & $2.613^{a}$ & $-0.085^{a}$ & $0.004^{a}$ & 0.000 & (3) \\
\hline & 1.299 & -0.018 & -0.018 & 0.002 & (3) \\
\hline \multirow[t]{2}{*}{$\mathrm{CsCl}$} & 5.996 & -0.063 & 0.000 & 0.004 & This study \\
\hline & $2.400^{\circ}$ & $-0.074^{a}$ & $0.000^{a}$ & 0.001 & (3) \\
\hline KI & $2.708^{a}$ & $-0.008^{a}$ & $0.004^{a}$ & 0.000 & (3) \\
\hline $\mathrm{MgCl}_{2}$ & $2.073^{a}$ & $0.382^{a}$ & $-0.016^{a}$ & 0.002 & (3) \\
\hline $\mathrm{CaCl}_{2}$ & $2.450^{a}$ & $0.329^{a}$ & $-0.010^{a}$ & 0.001 & (3) \\
\hline $\mathrm{BaCl}_{2}$ & $0.815^{a}$ & $0.180^{\circ}$ & $-0.052^{\circ}$ & 0.000 & (3) \\
\hline $\mathrm{HNO}_{3}$ & 27.198 & 0.136 & -0.003 & 0.049 & (3) \\
\hline $\mathrm{NaNO}_{3}$ & 0.941 & -0.042 & -0.008 & 0.001 & (3) \\
\hline $\mathrm{KNO}_{3}$ & 0.791 & -0.120 & -0.012 & 0.002 & (3) \\
\hline $\mathrm{Na}_{2} \mathrm{SO}_{4}$ & 0.563 & -0.303 & -0.065 & 0.002 & (3) \\
\hline $\mathrm{K}_{2} \mathrm{SO}_{4}$ & 0.459 & -0.510 & -0.043 & 0.001 & (3) \\
\hline KF & $0.330^{\circ}$ & $-0.980^{\circ}$ & $-0.989^{e}$ & 0.081 & (3) \\
\hline
\end{tabular}

${ }^{a}$ Values at $18^{\circ} \mathrm{C}$; units mol $\cdot \mathrm{kg}^{-1}$ for this column.

${ }^{b} a_{0}=0.167, a_{1}=0.002$.

${ }^{\prime} a_{0}=0.062, a_{1}=-0.005$.

${ }_{a_{0}}=-0.051, a_{1}=-0.002$.

'Values at $30^{\circ} \mathrm{C}$.

(3) (Linke, 1958)

Note 1 . See Figure 5 of this report for an explanation of the fitting parameters $a_{0}$ and $a_{1}$. 


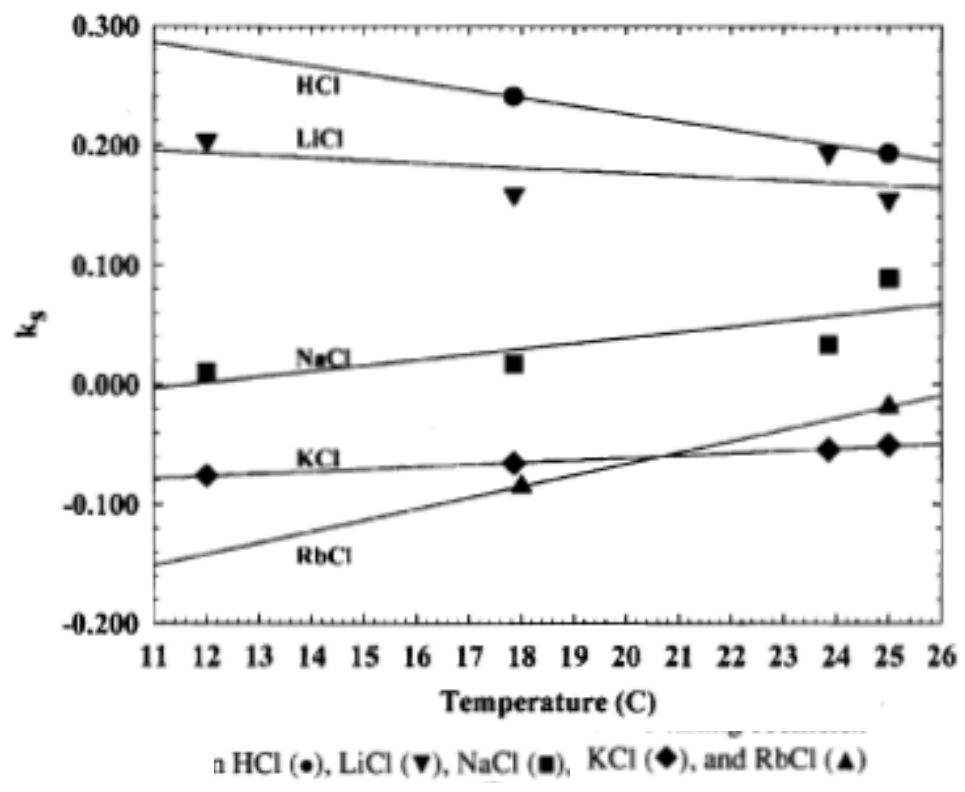

fitted by

$$
a=a_{0}+a_{1}(25-t)
$$

Note 1. See Table 5 for actual values of associated adjustable parameters $\mathrm{a}_{0}$ and $\mathrm{a}_{1}$ used.

Figure 5. The Salting Coefficients, $\mathbf{k}_{\mathrm{s}}$, of Boric Acid in $\mathrm{HCl}, \mathrm{LiCl}, \mathrm{NaCl}, \mathrm{KCl}$, and $\mathrm{RbCl}$ as a Function of Temperature ( $t$ in ${ }^{\circ} \mathrm{C}$ ) (Chanson, 2006). 
Table 6. Pitzer Parameters $\lambda_{\mathrm{B}-\mathrm{i}}$ and $\zeta_{\mathrm{B}-\mathrm{a}-\mathrm{c}}$ for the Solubility of Boric Acid (Chanson, 2006).

\begin{tabular}{lclr}
\hline Ion & $\lambda_{(\mathrm{B}-\mathrm{i})}$ & $\mathrm{C}-\mathrm{a}$ & $\zeta \mathrm{B}-\mathrm{c}-\mathrm{a}$ \\
\hline $\mathrm{H}^{+}$ & 0.109 & $\mathrm{H}-\mathrm{Cl}$ & -0.021 \\
$\mathrm{Li}^{+}$ & 0.087 & $\mathrm{Li}-\mathrm{Cl}$ & -0.004 \\
$\mathrm{Na}^{+}$ & 0.028 & $\mathrm{Na}-\mathrm{Cl}$ & -0.008 \\
$\mathrm{~K}^{+}$ & -0.026 & $\mathrm{~K}-\mathrm{Cl}$ & 0.001 \\
$\mathrm{Rb}^{+}$ & -0.026 & $\mathrm{Rb}-\mathrm{Cl}$ & -0.006 \\
$\mathrm{Cs}^{+}$ & -0.035 & $\mathrm{Cs}-\mathrm{Cl}$ & 0.000 \\
$\mathrm{Mg}^{2+}$ & $0.191^{a}$ & $\mathrm{Mg}-\mathrm{Cl}$ & $-0.016^{a}$ \\
$\mathrm{Ca}^{2+}$ & $0.165^{a}$ & $\mathrm{Ca}-\mathrm{Cl}$ & $-0.010^{a}$ \\
$\mathrm{Sr}^{2+}$ & $0.141^{b}$ & & \\
$\mathrm{Ba}^{2+}$ & $0.090^{a}$ & $\mathrm{Ba}-\mathrm{Cl}$ & $-0.052^{a}$ \\
$\mathrm{~F}^{-}$ & $-0.465^{c}$ & $\mathrm{~K}-\mathrm{F}$ & $-0.989^{c}$ \\
$\mathrm{Cl}^{-}$ & 0.000 & & \\
$\mathrm{Br}^{-}$ & $0.007^{d}$ & & \\
$\mathrm{I}^{-}$ & $0.022^{a}$ & $\mathrm{~K}-\mathrm{I}$ & $0.004^{a}$ \\
$\mathrm{NO}_{3}^{-}$ & $-0.041^{e}$ & $\mathrm{H}-\mathrm{NO}{ }_{3}$ & -0.003 \\
& & $\mathrm{Na}-\mathrm{NO}$ & -0.008 \\
& & $\mathrm{~K}-\mathrm{NO}{ }_{3}$ & -0.012 \\
$\mathrm{SO}_{4}^{2-}$ & $-0.205^{f}$ & $\mathrm{Na}-\mathrm{SO}_{4}$ & -0.065 \\
& & $\mathrm{~K}-\mathrm{SO}_{4}$ & -0.043 \\
\hline
\end{tabular}

${ }^{\mathrm{a}}$ Values at $18^{\circ} \mathrm{C}$.

${ }^{\mathrm{b}}$ Calculated from $\mathrm{K}_{\mathrm{s}}\left(\mathrm{SrCl}_{2}\right)$ in Table 7.

${ }^{\mathrm{C}}$ Values at $30^{\circ} \mathrm{C}$.

${ }^{\mathrm{d}}$ Calculated from $\mathrm{K}_{\mathrm{s}}(\mathrm{KBr})$ in Table 7.

${ }^{\mathrm{e}}-0.029$ from $\mathrm{H}^{+},-0.045$ from $\mathrm{Na}^{+}$, and -0.035 from $\mathrm{K}^{+}$.

${ }^{\mathrm{f}}-0.199$ from $\mathrm{Na}^{+}$and -0.205 from $\mathrm{K}^{+}$. 
Table 7. Partial Molal Volume of the Salts and the Best Current Estimated Salting Coefficients and Pitzer Parameter $\zeta_{\mathrm{B}-\mathrm{a}-\mathrm{c}}$ (Chanson, 2006).

\begin{tabular}{|c|c|c|c|c|c|c|}
\hline Salt & $\left(V_{\text {salt }}^{\circ}\right)^{a}$ & $\left(k_{\mathrm{s}}\right)^{b}$ & $\left(k_{s}\right)^{c}$ & Cation & Anion & $\left(\zeta_{\mathrm{B}-\mathrm{c}-\mathrm{a}}\right)^{d}$ \\
\hline $\mathrm{HCl}$ & 14.9 & 0.217 & 0.217 & $\mathrm{H}$ & $\mathrm{Cl}$ & -0.021 \\
\hline $\mathrm{LiCl}$ & 15.4 & 0.173 & 0.173 & $\mathrm{Li}$ & $\mathrm{Cl}$ & -0.004 \\
\hline $\mathrm{NaCl}$ & 17.0 & 0.055 & 0.055 & $\mathrm{Na}$ & $\mathrm{Cl}$ & -0.008 \\
\hline $\mathrm{KCl}$ & 20.8 & -0.051 & -0.051 & K & $\mathrm{Cl}$ & 0.001 \\
\hline $\mathrm{RbCl}$ & 23.1 & -0.051 & -0.052 & $\mathrm{Rb}$ & $\mathrm{Cl}$ & -0.006 \\
\hline $\mathrm{CsCl}$ & 27.1 & -0.069 & -0.069 & $\mathrm{Cs}$ & $\mathrm{Cl}$ & 0.000 \\
\hline $\mathrm{MgCl}_{2}$ & 30.5 & 0.382 & 0.382 & $\mathrm{Mg}$ & $\mathrm{Cl}$ & -0.016 \\
\hline $\mathrm{CaCl}_{2}$ & 32.2 & 0.329 & 0.329 & $\mathrm{Ca}$ & $\mathrm{Cl}$ & 0.010 \\
\hline $\mathrm{SrCl}_{2}$ & 33.4 & $0.283^{e}$ & 0.283 & & & \\
\hline $\mathrm{BaCl}_{2}$ & 36.0 & 0.180 & 0.180 & $\mathrm{Ba}$ & $\mathrm{Cl}$ & -0.052 \\
\hline $\mathrm{HBr}$ & 18.7 & 0.230 & 0.230 & & & \\
\hline $\mathrm{LiBr}$ & 19.2 & 0.186 & 0.186 & & & \\
\hline $\mathrm{NaBr}$ & 20.8 & 0.068 & 0.068 & & & \\
\hline $\mathrm{KBr}$ & 24.6 & $-0.038^{f}$ & -0.038 & & & \\
\hline $\mathrm{RbBr}$ & 26.9 & -0.039 & -0.039 & & & \\
\hline $\mathrm{CsBr}$ & 30.9 & -0.056 & -0.056 & & & \\
\hline $\mathrm{MgBr}_{2}$ & 38.1 & 0.409 & 0.409 & & & \\
\hline $\mathrm{CaBr}_{2}$ & 39.8 & 0.356 & 0.356 & & & \\
\hline $\mathrm{SrBr}_{2}$ & 41.0 & 0.310 & 0.310 & & & \\
\hline $\mathrm{BaBr}_{2}$ & 43.6 & 0.207 & 0.207 & & & \\
\hline HI & 25.4 & 0.260 & 0.260 & $\mathrm{H}$ & I & -0.018 \\
\hline Lil & 25.9 & 0.216 & 0.216 & $\mathrm{Li}$ & I & -0.001 \\
\hline $\mathrm{NaI}$ & 27.5 & 0.098 & 0.098 & $\mathrm{Na}$ & I & -0.005 \\
\hline KI & 31.3 & -0.008 & -0.008 & $\mathbf{K}$ & I & 0.004 \\
\hline RbI & 33.6 & -0.009 & -0.009 & $\mathbf{R b}$ & $\mathbf{I}$ & -0.003 \\
\hline CsI & 37.6 & -0.026 & -0.026 & $\mathrm{Cs}_{\mathrm{s}}$ & I & 0.003 \\
\hline $\mathrm{Mgl}_{2}$ & 51.5 & 0.468 & 0.468 & $\mathrm{Mg}$ & $\mathbf{I}$ & -0.010 \\
\hline $\mathrm{Cal}_{2}$ & 53.2 & $0.4 I$ & 0.415 & $\mathrm{Ca}$ & I & -0.004 \\
\hline $\mathrm{Srl}_{2}$ & 54.4 & $0.372^{8}$ & 0.369 & & & \\
\hline $\mathrm{Bal}_{2}$ & 57.0 & 0.266 & 0.266 & $\mathrm{Ba}$ & I & -0.046 \\
\hline $\mathrm{HNO}_{3}$ & 21.1 & 0.136 & 0.135 & $\mathrm{H}$ & $\mathrm{NO}_{3}$ & -0.003 \\
\hline $\mathrm{LiNO}_{3}$ & 21.6 & 0.094 & $0.09 I$ & $\mathrm{Li}$ & $\mathrm{NO}_{3}$ & -0.002 \\
\hline $\mathrm{NaNO}_{3}$ & 23.2 & -0.042 & -0.027 & $\mathrm{Na}$ & $\mathrm{NO}_{3}$ & -0.008 \\
\hline $\mathrm{KNO}_{3}$ & 27.0 & -0.120 & -0.133 & $\mathrm{~K}$ & $\mathrm{NO}_{3}$ & -0.012 \\
\hline $\mathrm{RbNO}_{3}$ & 29.3 & -0.134 & -0.134 & $\mathrm{Rb}$ & $\mathrm{NO}_{3}$ & -0.004 \\
\hline $\mathrm{CsNO}_{3}$ & 33.3 & -0.151 & -0.151 & $\mathrm{Cs}$ & $\mathrm{NO}_{3}$ & 0.002 \\
\hline $\mathrm{Mg}\left(\mathrm{NO}_{3}\right)_{2}$ & 42.9 & 0.217 & 0.217 & $\mathrm{Mg}$ & $\mathrm{NO}_{3}$ & -0.013 \\
\hline $\mathrm{Ca}\left(\mathrm{NO}_{3}\right)_{2}$ & 44.6 & 0.164 & 0.164 & $\mathrm{Ca}$ & $\mathrm{NO}_{3}$ & -0.007 \\
\hline $\mathrm{Sr}\left(\mathrm{NO}_{3}\right)_{2}$ & 45.8 & $0.120^{h}$ & 0.118 & & & \\
\hline $\mathrm{Ba}\left(\mathrm{NO}_{3}\right)_{2}$ & 48.4 & 0.015 & 0.015 & $\mathrm{Ba}$ & $\mathrm{NO}_{3}$ & -0.049 \\
\hline $\mathrm{H}_{2} \mathrm{SO}_{4}$ & 21.7 & 0.024 & 0.024 & $\mathrm{H}$ & $\mathrm{SO}_{4}$ & -0.089 \\
\hline $\mathrm{Li}_{2} \mathrm{SO}_{4}$ & 22.7 & -0.065 & -0.065 & $\mathrm{Li}$ & $\mathrm{SO}_{4}$ & -0.055 \\
\hline $\mathrm{Na}_{2} \mathrm{SO}_{4}$ & 25.9 & -0.303 & -0.301 & $\mathrm{Na}$ & $\mathrm{SO}_{4}$ & -0.065 \\
\hline $\mathrm{K}_{2} \mathrm{SO}_{4}$ & 33.5 & -0.510 & -0.513 & K & $\mathrm{SO}_{4}$ & -0.043 \\
\hline
\end{tabular}


SRNL-STI-2011-00578

Revision 0

Table 7. (Continued).

\begin{tabular}{lllllll}
\hline $\mathrm{Rb}_{2} \mathrm{SO}_{4}$ & 38.1 & -0.515 & -0.515 & $\mathrm{Rb}$ & $\mathrm{SO}_{4}$ & -0.059 \\
$\mathrm{Cs}_{2} \mathrm{SO}_{4}$ & 46.1 & -0.549 & -0.549 & $\mathrm{Cs}$ & $\mathrm{SO}_{4}$ & -0.047 \\
$\mathrm{MgSO}_{4}$ & 22.4 & -0.029 & -0.029 & $\mathrm{Mg}$ & $\mathrm{SO}_{4}$ & -0.117 \\
$\mathrm{CaSO}_{4}$ & 24.1 & -0.082 & -0.082 & $\mathrm{Ca}$ & $\mathrm{SO}_{4}$ & -0.111 \\
$\mathrm{SrSO}_{4}$ & 25.3 & $-0.128^{i}$ & -0.128 & & & \\
$\mathrm{BaSO}_{4}$ & 27.9 & -0.230 & -0.231 & $\mathrm{Ba}$ & $\mathrm{SO}_{4}$ & -0.153 \\
\hline
\end{tabular}

"Calculated from $V_{\text {crys: }}^{\circ}{ }^{(15,17)}$

${ }^{b}$ The italic values of this column are calculated from Eq. (18).

'The italic values of this column are calculated from Eq. (2).

${ }^{d}$ The italic values of this column are calculated from Eq. (20).

$' k_{\mathrm{s}}=-0.037 V_{\text {salt }}^{\prime \prime}-1.519$ using $k \mathrm{~s}$ values of $\mathrm{MgCl}_{2}, \mathrm{CaCl}_{2}$, and $\mathrm{BaCl}_{2}$.

$f_{k \mathrm{~S}}=0.004 V_{\text {salt }}^{\circ}-0.106$ using $k \mathrm{~s}$ values of $\mathrm{KCl}$ and $\mathrm{KI}$.

${ }^{8} \mathrm{ks}=-0.037 V_{\text {salt }}^{\mathrm{a}}-2.385$ using $k \mathrm{~s}$ values of $\mathrm{MgI}_{2}, \mathrm{Cal}_{2}$, and $\mathrm{Bal}_{2}$.

$h_{k \mathrm{~S}}=-0.037 V_{\text {salt }}^{\circ}-1.815$ using $k \mathrm{~s}$ values of $\mathrm{Mg}\left(\mathrm{NO}_{3}\right)_{2}, \mathrm{Ca}\left(\mathrm{NO}_{3}\right)_{2}$, and $\mathrm{Ba}\left(\mathrm{NO}_{3}\right)_{2}$.

$i_{\mathrm{ks}}=-0.037 \mathrm{~V}_{\mathrm{salt}}^{\mathrm{a}}-0.808$ using $\mathrm{k}_{5}$ values of $\mathrm{MgSO}_{4}, \mathrm{CaSO}_{4}$, and $\mathrm{BaSO}_{4}$.

Note: The equation numbers in notes b, c, and d refer to equations in the original reference by Chanson (2006). 
SRNL-STI-2011-00578

Revision 0

\section{Appendix C}


Table 8. Solubility Data in the System $\mathrm{Na}_{2} \mathrm{O}-\mathrm{B}_{2} \mathrm{O}_{3}-\mathrm{H}_{2} \mathrm{O}$ (Nies and Hulbert, 1967).

$\begin{array}{ll}0: 1: 3 & =\mathrm{H}_{3} \mathrm{BO}_{3} \\ 1: 1: 1 & =\mathrm{Na}_{2} \mathrm{O} \cdot \mathrm{B}_{2} \mathrm{O}_{3} \cdot \mathrm{H}_{2} \mathrm{O} \text { or } \mathrm{NaBO}_{2} \cdot 0.5 \mathrm{H}_{2} \mathrm{O} \\ 1: 1: 4 & =\mathrm{Na}_{2} \mathrm{O} \cdot \mathrm{B}_{2} \mathrm{O}_{3} \cdot 4 \mathrm{H}_{2} \mathrm{O} \text { or } \mathrm{NaBO}_{2} \cdot 2 \mathrm{H}_{2} \mathrm{O} \\ 1: 1: 8 & =\mathrm{Na}_{2} \mathrm{O} \cdot \mathrm{B}_{2} \mathrm{O}_{3} \cdot 8 \mathrm{H}_{2} \mathrm{O} \text { or } \mathrm{NaBO}_{2} \cdot 4 \mathrm{H}_{2} \mathrm{O} \\ 1: 2: 4 & =\mathrm{Na}_{2} \mathrm{O} \cdot 2 \mathrm{~B}_{2} \mathrm{O}_{3} \cdot 4 \mathrm{H}_{2} \mathrm{O} \\ 1: 2: 5 & =\mathrm{Na}_{2} \mathrm{O} \cdot 2 \mathrm{~B}_{2} \mathrm{O}_{3} \cdot 5 \mathrm{H}_{2} \mathrm{O} \\ 1: 2: 10 & =\mathrm{Na}_{2} \mathrm{O} \cdot 2 \mathrm{~B}_{2} \mathrm{O}_{3} \cdot 10 \mathrm{H}_{2} \mathrm{O} \\ 1: 5: 10 & =\mathrm{Na}_{2} \mathrm{O} \cdot 5 \mathrm{~B}_{2} \mathrm{O}_{3} \cdot 10 \mathrm{H}_{2} \mathrm{O} \text { or } \mathrm{NaB}_{3} \mathrm{O}_{3} \cdot 5 \mathrm{H}_{2} \mathrm{O} \\ 2: 5: 5 & =2 \mathrm{Na}_{2} \mathrm{O} \cdot 5 \mathrm{~B}_{2} \mathrm{O}_{3} \cdot 5 \mathrm{H}_{2} \mathrm{O} \\ 2: 5.1: 7 & =2 \mathrm{Na}_{2} \mathrm{O} \cdot 5 \cdot 1 \mathrm{~B}_{2} \mathrm{O}_{3} \cdot 7 \mathrm{H}_{2} \mathrm{O} \\ 2: 9: 11 & =2 \mathrm{Na}_{2} \mathrm{O} \cdot 9 \mathrm{~B}_{2} \mathrm{O}_{3} \cdot 11 \mathrm{H}_{2} \mathrm{O} \\ (\mathrm{m}) & =\text { Metastable }\end{array}$

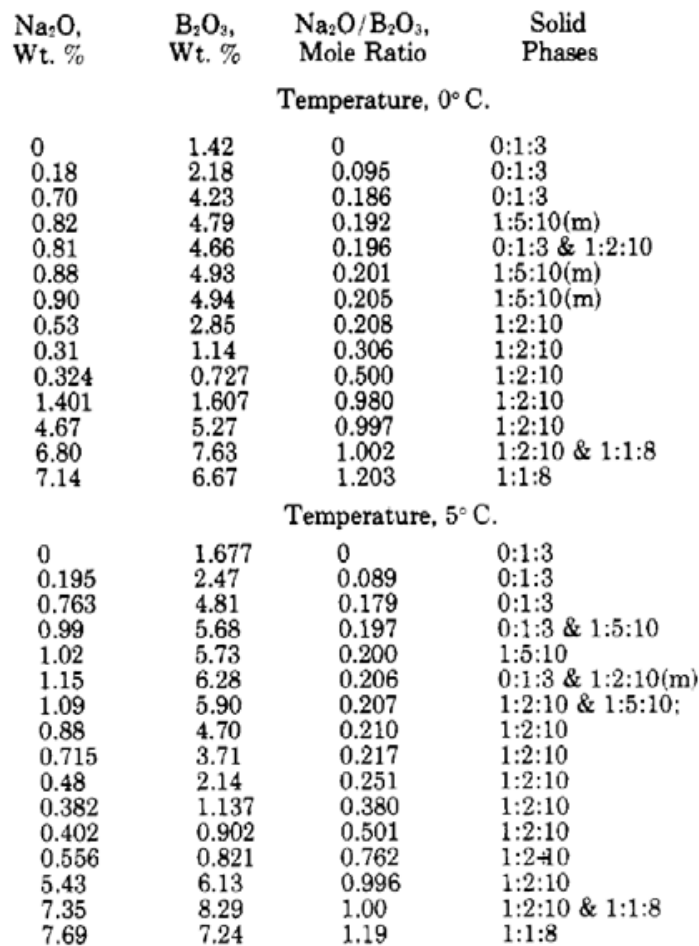

Temperature, $10^{\circ} \mathrm{C}$.

$\begin{array}{llll}0 & 1.967 & 0 & 0: 1: 3 \\ 0.27 & 3.11 & 0.096 & 0: 1: 3 \\ 0.73 & 4.97 & 0.164 & 0: 1: 3 \\ 1.13 & 6.57 & 0.193 & 0: 1: 3 \& 1: 5: 10 \\ 1.21 & 6.74 & 0.201 & 1: 5: 10 \\ 1.65 & 8.62 & 0.215 & 0: 1: 3 \& 1: 2: 10(\mathrm{~m}) \\ 1.36 & 7.04 & 0.217 & 1: 5: 10 \& 1: 2: 10 \\ 1.21 & 6.2 & 0.220 & 1: 2: 10 \\ 0.90 & 4.4 & 0.229 & 1: 2: 10 \\ 0.70 & 3.2 & 0.246 & 1: 2: 10 \\ 0.56 & 2.25 & 0.279 & 1: 2: 10 \\ 0.502 & 1.78 & 0.317 & 1: 2: 10 \\ 0.499 & 1.125 & 0.500 & 1: 2: 10 \\ 0.555 & 1.02 & 0.612 & 1: 2: 10 \\ 0.632 & 1.00 & 0.710 & 1: 2: 10 \\ 0.997 & 1.26 & 0.888 & 1: 2: 10 \\ 2.23 & 2.595 & 0.975 & 1: 2: 10 \\ 5.38 & 6.10 & 0.991 & 1: 2: 10 \\ 8.03 & 9.05 & 0.996 & 1: 2: 10 \& 1: 1: 8 \\ 8.13 & 8.24 & 1.110 & 1: 1: 8 \\ 8.36 & 7.72 & 1.218 & 1: 1: 8 \\ & & \text { Temperature, } 20^{\circ} \mathrm{C} . \\ 0 & 2.66 & 0 & 0: 1: 3 \\ 0.373 & 4.29 & 0.098 & 0: 1: 3 \\ 0.97 & 6.80 & 0.160 & 0: 1: 3 \\ 1.43 & 8.68 & 0.1855 & 0: 1: 3 \& 1: 5: 10 \\ 1.59 & 8.96 & 0.200 & 1: 5: 10 \\ 1.87 & 9.56 & 0.220 & 1: 5: 10 \\ 3.45 & 16.41 & 0.236 & 0: 1: 3 \& 1: 2: 10(\mathrm{~m})^{\circ} \\ 2.19 & 10.35 & 0.238 & 1: 5: 10 \& 1: 2: 10\end{array}$


Table 8. (Continued).

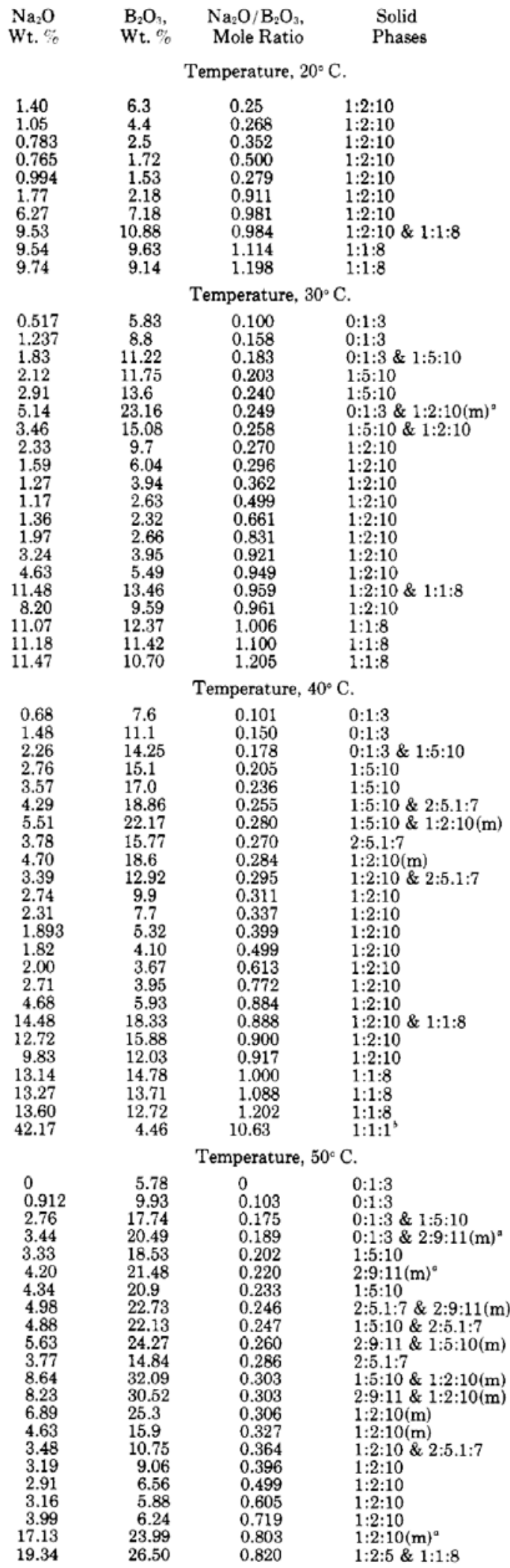


Table 8. (Continued).

\begin{tabular}{|c|c|c|c|}
\hline $\begin{array}{l}\mathrm{Na}_{2} \mathrm{O}, \\
\text { Wt. \% }\end{array}$ & $\begin{array}{l}\mathrm{B}_{2} \mathrm{O}_{3}, \\
\text { Wt. \% }\end{array}$ & $\begin{array}{l}\mathrm{Na}_{2} \mathrm{O} / \mathrm{B}_{2} \mathrm{O}_{3}, \\
\text { Mole Ratio }\end{array}$ & $\begin{array}{l}\text { Solid } \\
\text { Phases }\end{array}$ \\
\hline \multicolumn{4}{|c|}{ Temperature, $50^{\circ} \mathrm{C}$. } \\
\hline $\begin{array}{r}19.62 \\
6.36 \\
16.94 \\
13.27 \\
8.51 \\
17.67 \\
16.17 \\
16.02 \\
16.12 \\
16.56\end{array}$ & $\begin{array}{r}26.90 \\
8.70 \\
22.81 \\
17.83 \\
11.35 \\
22.25 \\
18.25 \\
17.90 \\
16.74 \\
15.95\end{array}$ & $\begin{array}{l}0.820 \\
0.821 \\
0.835 \\
0.837 \\
0.842 \\
0.893 \\
0.996 \\
1.006 \\
1.082 \\
1.167\end{array}$ & $\begin{array}{l}1: 2: 5 \& 1: 1: 4(\mathrm{~m}) \\
1: 2: 10 \\
1: 2: 5 \\
1: 2: 5 \\
1: 2: 10 \\
1: 1: 8 \\
1: 1: 8 \\
1: 1: 8 \\
1: 1: 8 \\
1: 1: 8\end{array}$ \\
\hline \multicolumn{4}{|c|}{ Temperature, $60^{\circ} \mathrm{C}$} \\
\hline 0 & 7.22 & 0.000 & $0: 1: 3$ \\
\hline 1.04 & 11.9 & 0.098 & $0: 1: 3$ \\
\hline 2.08 & 16.5 & 0.142 & $0: 1: 3$ \\
\hline 3.36 & 21.77 & 0.174 & $0: 1: 3 \& 1: 5: 10$ \\
\hline 3.58 & 22.60 & 0.178 & $0: 1: 3 \&$ 2:9:11(m) \\
\hline 3.97 & 22.62 & 0.198 & $1: 5: 10 \& 2: 9: 11$ \\
\hline 4.30 & 23.68 & 0.204 & $1: 5: 4(\mathrm{~m})^{\circ}$ \\
\hline 4.13 & 22.74 & 0.204 & $2: 9: 11$ \\
\hline 4.21 & 23.10 & 0.205 & $1: 5: 10(\mathrm{~m})$ \\
\hline 5.61 & 26.13 & 0.241 & $1: 5: 10 \& 2: 5.1: 7(\mathrm{~m})$ \\
\hline 5.40 & 24.83 & 0.245 & $2: 9: 11 \& 2: 5.1: 7$ \\
\hline 7.09 & 29.90 & 0.266 & $1: 5: 10(\mathrm{~m})$ \\
\hline 4.36 & 17.80 & 0.275 & $2: 5.1: 7$ \\
\hline 10.25 & 37.92 & 0.304 & $1: 5: 10 \& 1: 2: 4(\mathrm{~m})$ \\
\hline 9.18 & 33.29 & 0.310 & $1: 2: 4 \& 2: 9: 11(\mathrm{~m})$ \\
\hline 10.98 & 39.57 & 0.312 & $1: 5: 10 \& 1: 2: 5(\mathrm{~m})$ \\
\hline 11.85 & 41.84 & 0.318 & $1: 5: 10 \& 1: 2: 10(\mathrm{~m})$ \\
\hline 9.52 & 33.51 & 0.319 & $1: 2: 5(\mathrm{~m})$ \\
\hline 7.55 & 26.00 & 0.326 & $1: 2: 4(\mathrm{~m})$ \\
\hline 7.88 & 26.31 & 0.337 & $1: 2: 5(\mathrm{~m})$ \\
\hline 7.56 & 24.68 & 0.344 & $1: 2: 5(\mathrm{~m})$ \\
\hline 8.11 & 26.48 & 0.344 & $1: 2: 10(\mathrm{~m})^{a}$ \\
\hline 6.71 & 21.01 & 0.359 & $1: 2: 5(\mathrm{~m})^{6}$ \\
\hline 6.96 & 21.63 & 0.361 & $1: 2: 10(\mathrm{~m})^{\circ}$ \\
\hline 3.94 & 11.83 & 0.375 & $2: 5.1: 7$ \\
\hline 5.40 & 16.07 & 0.378 & $1: 2: 4(\mathrm{~m})$ \\
\hline 5.52 & 15.72 & 0.395 & $1: 2: 10$ \\
\hline 6.14 & 18.25 & 0.378 & $1: 2: 10(\mathrm{~m})^{a}$ \\
\hline 6.09 & 18.02 & 0.380 & $1: 2: 5(\mathrm{~m})^{6}$ \\
\hline 5.59 & 15.83 & 0.397 & $1: 2: 5(\mathrm{~m})$ \\
\hline 4.63 & 11.58 & 0.450 & $1: 2: 4 \& 2: 5.1: 7$ \\
\hline 5.01 & 12.45 & 0.452 & $1: 2: 10(\mathrm{~m})$ \\
\hline 5.11 & 12.71 & 0.452 & $1: 2: 5(\mathrm{~m})$ \\
\hline 4.95 & 11.89 & 0.468 & $1: 2: 10 \& 2: 5.1: 7(\mathrm{~m})$ \\
\hline 5.03 & 11.32 & 0.499 & $1: 2: 5(\mathrm{~m})$ \\
\hline 4.52 & 10.23 & 0.497 & $1: 2: 4$ \\
\hline 4.94 & 11.14 & 0.498 & $1: 2: 10(\mathrm{~m})$ \\
\hline 5.28 & 10.02 & 0.592 & $1: 2: 10(\mathrm{~m})$ \\
\hline 5.40 & 10.22 & 0.594 & $1: 2: 5(\mathrm{~m})$ \\
\hline 4.96 & 9.29 & 0.601 & $1: 2: 4$ \\
\hline 5.70 & 10.30 & 0.621 & $1: 2: 5(\mathrm{~m})^{b}$ \\
\hline 5.72 & 10.23 & 0.629 & $1: 2: 10(\mathrm{~m})^{\circ}$ \\
\hline 5.89 & 10.36 & 0.639 & $1: 2: 5(\mathrm{~m})^{2}$ \\
\hline 6.05 & 10.57 & 0.643 & $1: 2: 10(\mathrm{~m})^{\circ}$ \\
\hline 6.69 & 10.94 & 0.688 & $1: 2: 5(\mathrm{~m})^{6}$ \\
\hline 6.27 & 9.98 & 0.706 & $1: 2: 4$ \\
\hline 7.77 & 12.27 & 0.712 & $1: 2: 10(\mathrm{~m})^{a}$ \\
\hline 8.47 & 12.73 & 0.748 & $1: 2: 5(\mathrm{~m})$ \\
\hline 8.22 & 11.94 & 0.773 & $1: 2: 4$ \\
\hline 21.56 & 31.42 & 0.771 & $1: 2: 5 \& 1: 1: 4(\mathrm{~m})$ \\
\hline 12.00 & 16.92 & 0.797 & $1: 2: 5(\mathrm{~m})$ \\
\hline 18.83 & 26.45 & 0.800 & $1: 2: 5(\mathrm{~m})$ \\
\hline 15.65 & 21.83 & 0.806 & $1: 2: 5(\mathrm{~m})$ \\
\hline 20.66 & 28.58 & 0.813 & $1: 2: 4 \& 1: 1: 4$ \\
\hline 13.43 & 18.20 & 0.829 & $1: 2: 4$ \\
\hline 16.66 & 22.52 & 0.831 & $1: 2: 4$ \\
\hline 19.46 & 24.64 & 0.888 & $1: 1: 4$ \\
\hline 18.14 & 20.55 & 0.992 & $1: 1: 4$ \\
\hline 18.03 & 18.48 & 1.096 & $1: 1: 4$ \\
\hline 18.39 & 16.53 & 1.250 & $1: 1: 4$ \\
\hline 19.45 & 13.14 & 1.664 & $1: 1: 4$ \\
\hline & 9.52 & 2.57 & $\begin{array}{l}1: 1: 4 \\
1: 1: 4\end{array}$ \\
\hline & 6.31 & 5.07 & $1: 1: 4$ \\
\hline
\end{tabular}




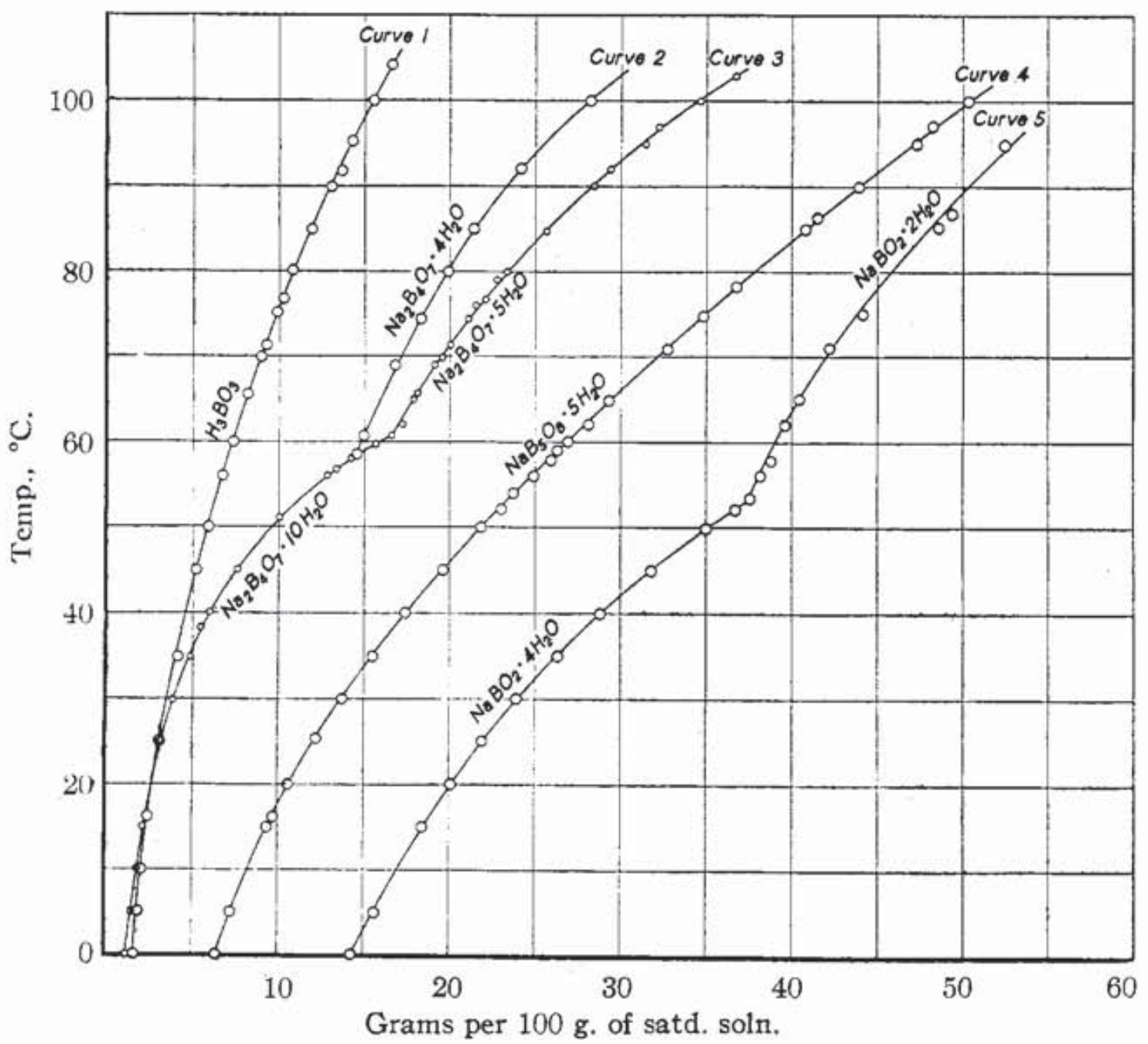

Figure 6. Solubility of Sodium Borates as Compared to Boric Acid ((Blasdale and Slansky, 1939). 


\section{Distribution:}

\begin{tabular}{|l|l|}
\hline A.B. Barnes, 999-W & D.H. McKenzie, 241-197H \\
J.M. Bricker, 704-27S & S.L. Marra, 773-A \\
H.H. Burns, 773-41A & B.A. Oard, 241-197H \\
K.P. Crapse, 773-A & J.E. Occhipinti, 704-S \\
R.E. Edwards, 773-67A & F.M. Pennebaker, 773-42A \\
T.L. Fellinger, 704-26S & T.B. Peters, 773-42A \\
S.D. Fink, 773-A & R.A. Pierce, 773-A \\
F.F. Fondeur, 773-A & H.P. Boyd, 704-27S \\
M. Geeting 241-152H & J.W. Ray, 704-S \\
B. Giddings, 786-5A & A. Samadi-Dezfouli, 241-197H \\
B.A. Gifford, 704-56H & D.C. Sherburne, 704-S \\
C.C. Herman, 999-W & A.V. Staub, 704-27S \\
E.W. Holtzscheiter, 704-15S & M.E. Stone, 999-W \\
J.F. Iaukea, 704-30S & K.H. Subramanian, 766-H \\
E. A. Kyser, 773-A & J.P. Vaughan, 773-41A \\
& \\
\hline
\end{tabular}

